Klinička psihologija 9 (2016), 2, 217-238

Izvorni znanstveni članak - UDK 159.937

DOI: 10.21465/2016-KP-2-0002

\title{
ŠTO USTVARI ISPITUJE TEST OČIJU? NEKE METODOLOŠKE TEŠKOĆE ISPITIVANJA TEORIJE UMA TESTOM OČIJU
}

\author{
Bruno Barać \\ Dom za djecu "Maestral" \\ Jurja Šišgorića 4, 21000 Split \\ baracbruno9@gmail.com \\ Anita Vulić-Prtorić \\ Odjel za psihologiju Sveučilišta u Zadru \\ Obala kralja Petra Krešimira IV br. 2, 23000 Zadar \\ avulic@unizd.hr
}

\begin{abstract}
Sažetak
Test čitanja misli iz očiju (Reading the Mind in Eyes Test - RMET, Baron-Cohen, Wheelwright, Hill, Raste i Plumb, 2001) ili kraće Test očiju jedan je od najčešće korištenih mjernih instrumenata za procjenu teorije uma u odraslih i to kako u istraživanjima, tako i u kliničkoj praksi. No, koliko god bio popularan, rijetki su radovi u kojima se navode psihometrijski pokazatelji za taj test. Stoga su u ovom radu postavljena dva glavna cilja: provesti analizu podataka iz dosadašnjih istraživanja u kojima se navode psihometrijski pokazatelji ovog testa, i usporediti ih s psihometrijskim karakteristikama dobivenim u uzorku ispitanika u našoj populaciji.

U istraživanju je sudjelovalo 97 ispitanica, studentica psihologije u Zadru. Osim Testa očiju korišten je Zadatak kratke priče (SST), kojim se ispituje kognitivna teorija uma, te Upitnik empatije (EPQ-IVE/A) i Torontska skala aleksitimije (TAS-20).

Podaci iz dosadašnjih istraživanja upozoravaju na brojne teškoće u konceptualizaciji Testa očiju, a analiza rezultata ispitivanja u našem uzorku nije doprinijela boljem razumijevanju predmeta mjerenja ovog testa. Osim niske pouzdanosti i upitne faktorske strukture, utvrđeno je da ne postoji povezanost s mjerama empatije i aleksitimije, te drugog aspekta teorije uma mjerenog Zadatkom kratke priče (SST).

S obzirom na to da je do danas Test očiju zauzeo važno mjesto u procjeni interpersonalnog funkcioniranja, te sposobnosti prepoznavanja emocija i procesiranja socijalnih informacija u kliničkim uzorcima, predlažu se postupci za moguća poboljšanja ovog mjernog instrumenta.
\end{abstract}

Ključne riječi: Test očiju, teorija uma, empatija, aleksitimija 


\section{UVOD}

Termin "teorija uma" prvi put su upotrijebili Premack i Woodruff 1978. godine da bi opisali sposobnost djeteta da opiše misli, osjećaje, ideje i namjere druge osobe i da tu sposobnost koristi kako bi predvidjelo ponašanje te druge osobe. Koristi se termin teorija kako bi se naglasilo da kada osoba koristi vlastite konstrukte ( $\mathrm{tj}$. povezuje ponašanja s mentalnim stanjima poput želja i vjerovanja) ona posjeduje okvir za tumačenje i predviđanje ponašanja drugih osoba. Ostali termini kojima se opisuje ovaj konstrukt su "mentalizacija", "čitanje misli", "socijalna inteligencija", a jednim svojim dijelom preklapa se s terminom "empatija" (Baron-Cohen i sur., 2001). Sam pojam je vrlo kompleksan jer obuhvaća sposobnost atribuiranja misli, vjerovanja i osjećaja drugim ljudima i sebi te shvaćanje da su te iste misli, vjerovanja i osjećaji pokretači našeg djelovanja (Dahlgren Sandberg i Dahlgren, 2012), a to su temeljni aspekti socijalne kognicije, koja upravlja i usmjerava socijalne interakcije $\mathrm{i}$ individualna ponašanja u nizu različitih situacija (Bernstein, Thornton $\mathrm{i}$ Sommerville, 2011).

Sposobnost promatranja svijeta iz perspektive druge osobe počinje se razvijati od kraja prve godine života (Remschmidt, 2009). Djeca u dobi između treće i pete godine prvi put uspješno rješavaju jednostavne zadatke teorije uma, odnosno zadatke zaključivanja prvog reda (zadataka lažnog vjerovanja). Ove sposobnosti najčešće se ispituju zadacima poput Sally $i$ Anne zadatak ili Smarties zadatak (Bernstein i sur., 2011). Zaključivanje prvog reda odnosi se na vjerovanje o neposrednim događajima, dok se zaključivanje drugog reda odnosi na vjerovanje o tome što netko drugi vjeruje o događajima (Miller, 2009). Na primjer, osoba X vjeruje da se knjiga za lektiru nalazi u dnevnoj sobi, što bi bilo zaključivanje prvog reda. Međutim, ako osoba $\mathrm{Y}$ vjeruje da osoba $\mathrm{X}$ vjeruje da se knjiga za lektiru nalazi u dnevnoj sobi, to se smatra zaključivanjem drugog reda. Zaključivanje drugog reda razvija se kasnije od zaključivanja prvog reda i to u dobi između šeste i sedme godine. Iako se velik broj istraživanja usredotočio na ispitivanje teorije uma kod djece, promjene u teoriji uma vidljive su kroz cijeli život. Prema nekim autorima starije odrasle osobe imaju više poteškoća u zaključivanju o mentalnim procesima drugih osoba od mlađih odraslih osoba, a dob nakon koje razlika u uspješnosti u zaključivanju o mentalnim procesima drugih osoba postaje značajna je 55 godina (Bernstein i sur., 2011).

Prva istraživanja teorije uma bila su u uzorcima djece s poremećajem iz spektra autizma jer se pokazalo da oko $80 \%$ te djece nije bilo u stanju ispravno predvidjeti što drugi misle (Šimleša, 2011). Devedesetih godina razvijen je čitav niz programa za uvježbavanje vještina teorije uma. Kako bi se te vježbe što bolje isplanirale i kasnije pratila njihova učinkovitost, razvijeni su mjerni instrumenti za procjenu teorije uma. Budući da se pokazalo da je teorija uma kompleksan konstrukt koji u sebi sadrži specifične kognitivne i emocionalne funkcije iz socijalne domene, većina tih instrumenata kombinirala je ispitne materijale u obliku priča, stripova i slika. (Muris i sur., 1999). Do danas je konstruirano nekoliko testova za ispitivanje teorije uma, koncipiranih u skladu s osnovnim podjelama i tumačenjima teorije uma. Temeljna 
podjela je na afektivnu i kognitivnu, te na sociokognitivnu i socio-perceptivnu teoriju uma. Afektivna teorija uma odnosi se na razumijevanje emocija drugih osoba, odnosno na emocionalnu komunikaciju, kao i na kognitivne procese koji sudjeluju u razumijevanju emocionalnih stanja druge osobe (Dennis i sur., 2013). Test očiju i Zadatak pogrešnog koraka (Faux pas) koriste se za ispitivanje ovog aspekta teorije uma. Socio-kognitivnu teoriju uma opisuju sposobnosti zaključivanja o mentalnim stanjima drugih osoba na temelju socijalnih i emocionalnih znanja (Ferguson i Austin, 2010). Zadaci za ispitivanje ovog aspekta teorije uma su priče (poput Zadatka kratke priče SST koji je korišten u našem istraživanju, te zadatka Pogrešnog koraka i Testa neobičnih priča) koje uključuju opisivanje vjerovanja i mišljenja pojedinaca (Nettle i Liddle, 2008). Zadatak Pogrešnog koraka (Faux Pas) sastoji se od 20 kratkih priča koje opisuju razne socijalne situacije, a zadatak ispitanika je da procijeni da li se glavni lik ponašao na neprimjeren način u određenoj situaciji. Test neobičnih priča (Strange Stories Test, Happé, 1994) sastoji se od 24 kratke pričice i slike u kojima osobe imaju različite motive kada govore nešto što baš i nije potpuno istinito. Ovaj zadatak služi za ispitivanje zadataka drugog reda koji se odnose na varke, a uključuje priče o laži, šali, pretvaranju, nesporazumu, uvjeravanju, stvarnosti nasuprot prikazivanju u boljem svjetlu, načinu na koji se neka riječ prikaže, sarkazmu, zaboravu, dvostrukoj obmani i oprečnim emocijama.

Socioperceptivna teorija uma opisuju sposobnosti donošenja brzih procjena o mentalnim stanjima drugih koristeći neverbalne znakove kao što su facijalne ekspresije i pokreti tijela. Povezana je s brzim procesiranjem novih informacija. Primjer zadatka kojim se ispituje ovaj aspekt teorije uma je Reading the Mind in the Eyes test (Baron-Cohen i sur., 2001). Test se sastoji od 36 slika očiju (Slika 1) koje prikazuju oči glumaca prilikom glumljenja različitih emocija, te liste od po četiri riječi koje se odnose na mentalno stanje prikazano na fotografiji. Zadatak ispitanika je odabrati jedan od četiri odgovora koji najbolje opisuje mentalno stanje osobe na slici, dok ostale tri riječi ne opisuju prikazanu emociju, ali imaju istu emocionalnu valenciju.

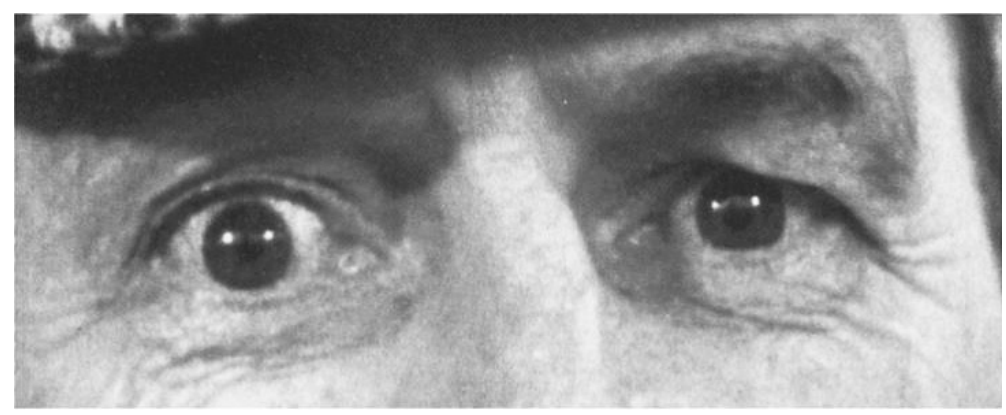

Slika 1 Primjer iz Testa očiju. Ponuđeni odgovori su: Ljubomorno, Uspaničeno (točan odgovor), Arogantno, Puno mržnje 
Test očiju prvi put su opisali Simon Baron-Cohen i suradnici 1997. godine (Baron-Cohen i sur., 2001). U toj prvoj verziji test se sastojao od 25 fotografija područja očiju i liste od po dva ponuđena odgovora. Rezultati primjene ove prve verzije testa pokazali su da osobe ženskog spola postižu nešto više prosječne rezultate, te da osobe s visokofunkcionirajućim autizmom ili Aspergerovim sindromom postižu značajno niže rezultate od osoba iz kontrolnih uzoraka (Baron-Cohen i sur., 2001).

Nakon niza provjera i dobivenih nalaza, autori su 2001. godine odlučili poboljšati test, te su povećali broj zadataka sa 25 na 36 fotografija, te broj ponuđenih odgovora sa 2 na 4 . U ponuđene odgovore umjesto opisa temeljnih emocija (sretan, tužan, uplašen i dr.) uvrstili su teže opise, tj. opise kompleksnijih mentalnih stanja koji uključuju kognitivno mentalno stanje osobe - vjerovanje i namjeru. Nadalje, iz ispitnih materijala isključene su one fotografije kod kojih se iz smjera u koji osoba na fotografiji gleda lako može zaključiti o mentalnom stanju te osobe. Budući da je prva verzija imala više fotografija sa ženskim licima, uravnotežen je broj fotografija na kojima su žene s onima na kojima su muškarci. Odgovori u prvoj verziji bili su uvijek semantički suprotni (suosjećajan vs. ravnodušan, pažljiv vs. nepažljiv) te se u novoj verziji vodilo računa da kad god je to moguće, tri netočna odgovora imaju isti emocionalni smjer kao i točan odgovor. Na taj način donošenje odluke o točnom odgovoru je postalo teže, ili kako autori kažu - umjesto odlučivanja o tome je li crno ili bijelo, sada se moralo odlučiti o tome koja nijansa sive je u pitanju. Na kraju, budući da test uključuje povezivanje slike s riječima, a želeći izbjeći mogućnost da neki ispitanik dobije manje bodova jer mu nije jasno što pojedina riječ u listi odgovora točno znači, autori su izradili rječnik u kojem se za svaki ponuđeni odgovor objašnjava značenje te riječi i daje primjer za ilustraciju.

Primjenom ove nove verzije testa u 4 uzorka odraslih - uzorku osoba s Aspergerovim sindromom, osoba s visokofunkcionirajućim autizmom i dva kontrolna uzorka - autori su zaključili da se test može koristiti za identifikaciju blagih oštećenja u socijalnoj inteligenciji inače prosječno inteligentnih osoba, te u razlikovanju osoba s težim oštećenjima u ovoj domeni. Na taj je način dobiven test socijalne osjetljivosti za odrasle kojim su se mogle ispitati teškoće u prepoznavanju mentalnih stanja druge osobe i to čak i na temelju minimalnih pokazatelja (ekspresije dijela lica oko očiju).

Test ispituje naprednu teoriju uma budući da mentalna stanja prikazana na slikama nisu osnovne emocije, već su to kompleksna mentalna stanja kao arogancija, dosada ili koketiranje. K tome, prema autorima, ovim testom se ispituje u kojoj mjeri ispitanik može zauzeti stajalište i mentalno stanje druge osobe. Test zahtijeva leksička i semantička znanja, i njihovo korištenje u opisivanju mentalnih stanja vidljivih iz fragmenta facijalne ekspresije - tj. dijela lica oko očiju. Ispitanici na nesvjesnoj, brzoj i automatskoj razini moraju upariti prezentiranu sliku očiju sa sličnim ekspresijama koje imaju pohranjene u pamćenju, povezati to s mentalnim stanjem i zatim s riječima kojima će to stanje opisati. Premda je ovo test napredne teorije uma, on mjeri samo jedan njezin dio, i to prvu razinu atribucije teorije uma: atribuciju 
relevantnog mentalnog stanja (tj. suosjećanje). Ne uključuje drugu razinu: sadržaj koji je u pozadini tog mentalnog stanja (npr. suosjećanje zbog gubitka drage osobe).

Cilj ovog rada je provjeriti psihometrijske kvalitete Testa očiju kroz dva postupka: u prvom se navodi pregled rezultata dosadašnjih ispitivanja psihometrijskih karakteristika ovog mjernog instrumenta, a u drugom će se provesti psihometrijska validacija na prigodnom uzorku studentica u Hrvatskoj.

\section{METODOLOGIJA}

\section{Ispitanici}

U istraživanju su sudjelovale studentice $(\mathrm{N}=97)$ studija psihologije u Zadru, dobi od 19 do 25 godina $\left(\mathrm{M}_{\mathrm{dob}}=21,14, \mathrm{SD}_{\mathrm{dob}}=1,69\right)$. Nekoliko je razloga za odabir uzorka studentica psihologije za ovo istraživanje: (1) mogućnost komparacije rezultata: naime, $u$ dosadašnjim istraživanjima uzorke odraslih osoba uglavnom su činili studenti i to najčešće studenti psihologije, a jedan od ciljeva ovog istraživanja je provjera psihometrijskih kvaliteta testa u našem uzorku na način da se pri tome što više pokušaju replicirati dosadašnji postupci validacije ovih mjernih instrumenata (npr. istraživanja Dodell-Feder, Lincoln, Coulson i Hooker, 2013.; Vellante i sur., 2013); (2) provjera razumljivosti testa: u nekim istraživanjima pokazalo se da je postignuće u ovom testu povezano s bogatstvom rječnika i razumijevanjem pojmova koji se koriste za opisivanje mentalnih stanja, a budući da je ovo prva primjena prijevoda testa na hrvatskom jeziku, učinilo se važnim odabrati ispitanike koji će dati povratnu informaciju o razumljivosti testa; (3) homogenost uzorka: budući da su dosadašnji nalazi o razlikama s obzirom na spol i dob u postignuću na ovom testu bili vrlo nekonzistentni (vidi u Jankowiak-Siuda, Baron-Cohen, Bialaszek, Dopierala, Kozlowska i Rymarczyk, 2016), odabirom samo ispitanica ženskog spola, i to studentica iste studijske grupe i malog dobnog raspona, pokušalo se postići što veću homogenost uzorka i izbjeći neke utjecajne ometajuće čimbenike koji bi se u ovakvom postupku mogli pojaviti.

\section{Mjerni instrumenti}

Rezultati prikazani u ovom radu dio su jednog opsežnijeg istraživanja u kojem su osim ovdje opisanih instrumenata primijenjene i mjere psihosomatskih simptoma, te ruminacije agresije. U svrhu ovog rada prikazani su rezultati psihometrijske analize Testa očiju (RMET) i njegove relacije s ostalim mjerama: kognitivnim aspektom teorije uma ispitanim Zadatkom kratke priče (SST), empatijom (EPQ IVE/A) i aleksitimijom (TAS-20). Za potrebe ovog istraživanja liste za odgovore za Test očiju i Zadatak kratke priče s engleskog su prevela dva psihologa i jedan jezični ekspert, a u skladu sa standardima prijevoda psiholoških mjernih instrumenata. 
Test čitanja misli u očima ili skraćeno Test očiju (Reading the Mind in the Eyes Test-RMET; Baron-Cohen i sur., 2001) - ispituje afektivni i socijalno perceptivni aspekt teorije uma. Sastoji se od 36 crno-bijelih fotografija područja očiju dimenzija $15 \times 10 \mathrm{~cm}$, koje prikazuju emocionalno nabijena ili neutralna mentalna stanja, te lista za odgovore. Cilj ovog testa je uparivanje semantičke definicije mentalnog stanja sa slikom koja prikazuje područje očiju. Za svaku sliku očiju ponuđene su četiri riječi, od kojih jedna odgovara mentalnom stanju, a preostale tri su pogrešne. Za točan odgovor ispitanik dobiva 1 bod, a za sve ostale odgovore 0 bodova.

Do danas je ovaj test korišten u preko 250 istraživanja (Baron-Cohen, Bowen, Holt, Allison, Auyeung, Lombardo, Smith, i Lai 2015) i preveden je na nekoliko jezika (francuski, španjolski, talijanski, japanski, rumunjski, švedski, turski, poljski i dr.). Test je primijenjen u brojnim istraživanjima u kojima su uspoređivani rezultati osoba iz kliničkih uzoraka (osobe s poremećajima iz spektra autizma, shizofrenijom, depresijom, anoreksijom, psihopatijom i dr.) pokazujući da se ovim testom uspješno mogu razlikovati vještine socijalne kognicije i teorije uma između kliničkih i kontrolnih uzoraka ispitanika. Unatoč čestom korištenju i popularnosti, pouzdanost i faktorska struktura ovog testa vrlo rijetko su ispitivane, a rezultati novijih provjera upućuju na cijeli niz teškoća u validaciji ovog testa (Baron-Cohen i sur. 2015; Jankowiak-Siuda i sur., 2016; Olderbak i sur., 2015; Vellante i sur., 2013).

Zadatak kratke priče (Short Story Task - SST; Dodell-Feder, i sur., 2013) ispituje kognitivni aspekt teorije uma. Sastoji se od kratke priče autora E. Hemingwaya "Svršetak nečega", te 14 pitanja vezanih uz tu priču. Kako bi razumio priču, ispitanik treba prilikom čitanja zaključivati (zaključivanja prvog i drugog reda) o mentalnim stanjima likova. Zadatak obuhvaća tri faktora: razumijevanje, te eksplicitno i spontano zaključivanje o mentalnim stanjima. Autori nude tablicu za ocjenjivanje zadataka po česticama i faktorima. Ocjenjivanje se vrši na skali od tri stupnja ( 0 , 1,2), gdje 0 upućuje na nerazumijevanje teksta i mentalnih stanja likova, 1 na djelomično razumijevanje, a 2 upućuje na potpuno razumijevanje teksta i mentalnih stanja likova. Američki uzorak za provjeru metrijskih karakteristika ovog zadatka činila su 74 ispitanika (27 muškaraca i 47 žena), a dobivena je niska unutarnja pouzdanost tipa Cronbach alpha $(\alpha=0,54)$ za čestice koje su se odnosile na zaključivanje o mentalnim stanjima, te $\alpha=0,31$ za čestice koje su se odnosile na razumijevanje teksta.

Metrijske karakteristike SST-a provjerene su na našem uzorku studentica. Faktorskom analizom (metoda zajedničkih faktora i Kaiser-Guttmanov kriterij ekstrakcije faktora s karakterističnim korijenom većim od 1) dobiven je 1 faktor koji objašnjava 11,5\% zajedničke varijance. Od ukupno 14 čestica SSTa, 5 nije imalo zasićenje veće od 0,30 . Od preostalih 6 čestica, 5 ih originalno pripada faktoru $E k$ splicitno zaključivanje o mentalnim stanjima, a 1 Spontano zaključivanje o mentalnim stanjima. Budući da je ovih 6 čestica pokazalo zadovoljavajuće psihometrijske kvalitete, u daljnjim analizama korištena je skraćena verzija Zadatka kratke pri- 
če-Zaključivanje o mentalnim stanjima drugih (koeficijent pouzdanosti Cronbach alpha iznosi 0,63) (Tablica 1).

Upitnik empatije je jedan od upitnika iz Eysenckove skale ličnosti (EPQ IVE/A; Eysenck i Eysenck, 1994) koja se sastoji od 54 čestice, te mjeri tri dimenzije ličnosti: impulzivnost, avanturizam i empatiju. Dimenziju empatije, koja je korištena u ovom istraživanju, čini 19 čestica. U uzorku žena za ovaj upitnik utvrđen je koeficijent pouzdanosti Cronbach alpha 0,69 (Eysenck i Eysenck, 1994). Za potrebe ovog istraživanja provjerene su metrijske karakteristike upitnika, i budući da je verzija od 19 čestica imala pouzdanost Cronbach alpha 0,59, te da je 11 čestica imalo izrazito niska faktorska zasićenja i korelaciju čestice s ukupnim rezultatom na skali (manju od 0,30), u daljnjoj analizi rezultata korišteno je samo 8 čestica. Tako skraćena skala empatije imala je zadovoljavajuću pouzdanost Cronbach alpha od 0,71 (Tablica 1).

Torontska skala aleksitimije (Toronto Alexithymia Scale - TAS-20; Bagby, Parker i Taylor, 1994) sastoji se od 20 tvrdnji razvrstanih u tri podljestvice: Teškoće u identifikaciji osjećaja (7 čestica), Teškoće u opisivanju osjećaja drugim ljudima (5 čestica), Eksternalno orijentirano mišljenje (8 čestica). Na uzorku od 956 studenata prve i druge godine na Kanadskom sveučilištu autori su utvrdili zadovoljavajuće metrijske karakteristike ove skale $(\alpha=0,81)$. Na hrvatskom uzorku od 269 srednjoškolaca koeficijent pouzdanosti Cronbach alpha iznosio je 0,72 za cijelu skalu, dok je za pojedine podljestvice iznosio redom: 0,77 za Teškoće u identifikaciji osjećaja, 0,68 za Teškoće u opisivanju osjećaja drugim ljudima, te 0,38 za Eksternalno orijentirano mišljenje (Kulenović, Buško i Jenjić, 2004). Probleme s podljestvicom Eksternalno orijentirano mišljenje navode i drugi autori u istraživanjima kod nas (Gršković, 2010; Kocijan Lovko, Gelo i Karlović, 2015) i u svijetu (Taylor, Bagby

Tablica 1. Deskriptivni parametri primijenjenih mjernih instrumenata nakon provedenih analiza i njihova skraćivanja $(N=97)$

\begin{tabular}{lccccc}
\hline Mjerni instrumenti & Broj čestica & $M$ & $S D$ & Raspon & $\alpha$ \\
\hline $\begin{array}{l}\text { Zadatak kratke priče (SST) - } \\
\begin{array}{l}\text { Zaključivanje o mentalnim stanjima } \\
\text { drugih }\end{array}\end{array}$ & 6 & 7,45 & 2,54 & $2-12$ & 0,63 \\
$\begin{array}{l}\text { Upitnik empatije EPQ - IVE/A } \\
\begin{array}{l}\text { Torontska skala aleksitimije } \\
\text { TAS - 20) }\end{array}\end{array} \quad 16$ & 34,55 & 11,01 & $18-72$ & 0,87 \\
$\begin{array}{l}\text { Teškoće u identifikaciji osjećaja } \\
\begin{array}{l}\text { Teškoće u opisivanju osjećaja } \\
\text { drugim ljudima }\end{array}\end{array}$ & 7 & 15,27 & 6,28 & $7-30$ & 0,86 \\
Eksternalno orijentirano mišljenje & 5 & 12,45 & 4,88 & $5-25$ & 0,83 \\
\hline
\end{tabular}


i Parker, 2003), i to kako u verziji TAS-a od 20 tako i u verziji od 26 čestica. S druge strane, u nekim istraživanjima TAS-20 se pokazala visokopouzdanom, kao i sve tri njene podljestvice (Loas i sur., 2001; Muller, Buhner i Ellgring, 2003; Spitzer i sur., 2007).

Za potrebe ovog istraživanja provjerene su metrijske karakteristike upitnika TAS-20. U uzorku od 97 studentica zadovoljavajuću pouzdanost tipa Cronbach alpha imale su dvije podljestvice: Teškoće u identifikaciji osjećaja $(\alpha=0,86)$ i Teškoće u opisivanju osjećaja drugim ljudima $(\alpha=0,83)$ dok treća podljestvica, Eksternalno orijentirano mišljenje, nije imala zadovoljavajuću pouzdanost, te je za daljnje analize korištena skraćena verzija u koju su uvrštene samo one čestice koje su imale faktorsko zasićenje i korelaciju s ukupnim rezultatom na podljestvici veće od 0,30 . Tom kriteriju udovoljile su 4 čestice i tako skraćena podljestvica imala je pouzdanost tipa Cronbach alpa od 0,66 (Tablica 1).

\section{Postupak}

Ispitivanje je provedeno u manjim skupinama studentica, $u$ vrijeme redovite nastave na Sveučilištu. Sve liste za odgovore činile su jedan svezak. Na početku istraživanja ispitanice su ukratko upoznate s općom svrhom istraživanja, te su zamoljene da pažljivo pristupe rješavanju zadataka jer se radi o prvoj primjeni u Hrvatskoj. Ispitivanje je bilo anonimno, a po završetku ispitivanja ispitanice su mogle postavljati pitanja vezana za samo ispitivanje, te izvijestiti glede teškoća oko rješavanja pojedinih zadataka. Njihovi komentari su prikupljeni i bit će korišteni u daljnjoj validaciji navedenih mjernih instrumenata. Redoslijed ispitivanja bio je uvijek isti: prvo je svakoj ispitanici podijeljena priča "Svršetak nečega" autora E. Hemingwaya. Nakon što su sve ispitanice pročitale zadanu priču, podijeljeni su listovi za odgovore za Zadatak kratke priče i Test očiju, Upitnik empatije i Torontska skala aleksitimije. Za rješavanje Testa očiju ispitanice su dobile svezak s podražajnim materijalom od 36 fotografija očiju. Vrijeme rješavanja nije bilo ograničeno, a u prosjeku je trajalo oko 30 minuta. Ispitivanje su proveli autori rada.

\section{Statistička obrada podataka}

Za statističku obradu podataka korišten je program Statistica 12. Kako bi rezultati u ovom istraživanju bili komparabilni s rezultatima dosadašnjih istraživanja Testom očiju, u odabiru metoda statističke obrade podataka vodilo se računa da se koriste one metode koje preporučuju autori primijenjenih mjernih instrumenata. Normalnost distribucije dobivenih rezultata testirana je Kolmogorov-Smirnovljevim testom (K-S), povezanost među ispitivanim varijablama provjerena je Pearsonovim koeficijentom korelacije, a pouzdanost tipa unutrašnje konzistencije 
određena je Cronbachovim $\alpha$ koeficijentom. Faktorska analiza rezultata izvedena je metodom zajedničkih faktora uz Varimax rotaciju i Guttman-Kaiserovim kriterijem ekstrakcije faktora s karakterističnim korijenom većim od 1.

\section{REZULTATI I RASPRAVA}

U Tablici 2 prikazani su neki pokazatelji iz istraživanja u kojima je korišten Test očiju. Podaci su navedeni za naš uzorak i za komparabilne uzorke u drugim istraživanjima. U većem broju istraživanja uzorak su činili i muški i ženski ispitanici, ali se za potrebe ovog istraživanja, tj. usporedbe naših s rezultatima u drugim istraživanjima navode uglavnom podaci dobiveni u uzorcima ispitanica (gdje god je taj podatak bio dostupan).

Kao što se iz Tablice 2 može primijetiti, prosječne vrijednosti i standardne devijacije dobivene $u$ Testu očiju na našem uzorku nalaze se u rasponu vrijednosti u drugim istraživanjima. Sa $74 \%$ točno riješenih zadataka studentice u ovom istraživanju uspješne su u prepoznavanju kompleksnih emocionalno-mentalnih stanja iz prezentiranih slika očiju. Procjenjuje se da zdrave odrasle osobe uspješno rješavaju oko 70\% zadataka na Testu očiju (Harkness, Sabbagh, Jacobson, Chowdrey i Chen, 2005). U većini navedenih istraživanja, rezultati studentica su kvantitativno dosta viši od prosječnih vrijednosti tipičnih za kliničke uzork. Distribucija rezultata je (također očekivano) normalna (K-S, d =0,088, p >0,20).

U Tablici 2 također su navedeni podaci o pouzdanosti Testa očiju. Kao što se može primijetiti, u našem istraživanju (prvi red u tablici) pouzdanost tipa unutarnje konzistencije je relativno niska u usporedbi s nalazima iz ostalih istraživanja i iznosi Cronbach alpha 0,48 , a korelacije između rezultata na pojedinoj čestici i ukupnog rezultata pokazuju da čestice ne ispituju isti fenomen: prosječna korelacija među česticama iznosi 0,03. Podatak o pouzdanosti Testa očiju sve donedavno se rijetko navodio, premda je ovaj test često korišten u istraživanjima i kliničkom radu. Autori testa Baron-Cohen i suradnici (2015) navode da su od 2001. godine do danas rezultati primjene Testa očiju opisani u preko 250 radova. Vellante i suradnici (2013) u pregledu istraživanja u kojima su provjeravane neke psihometrijske karakteristike Testa očiju, nalaze da od 23 pregledana rada u samo njih 6 je naveden podatak o pouzdanosti testa. Kao najčešći razlog dobivanja niske pouzdanosti i slabe povezanosti među česticama navodi se nekonzistentnost u prezentaciji očiju na fotografijama (korištenje sjene i nejednakog osvjetljenja, različite usmjerenosti pogleda i sl.) ili teškoće u pronalasku adekvatnih riječi bilo zbog kvalitete prijevoda ili općenito, zbog manje poznatosti te riječi u jeziku na koji je prevedena (Baron-Cohen i sur., 2015; Hallerbäck, Lugnegard, Hjarthag i Gillberg, 2009; Olderbak i sur., 2015).

Bez obzira na razloge koji su u podlozi ovakvih rezultata, u takvim se slučajevima predlažu tri kriterija za procjenu valjanosti svake pojedine čestice i testa općenito za uzorak u kojem se ispitivanje vrši. 
Tablica 2. Istraživanja u kojima je korišten Test očiju

\begin{tabular}{|c|c|c|c|c|}
\hline Istraživanje (autori) & Uzorak & $M$ & $S D$ & $\alpha$ \\
\hline Naše istraživanje & 97 studentica & 26,7 & 3,49 & 0,49 \\
\hline Baron-Cohen i sur. (2001) & 50 studentica & 28,6 & 3,2 & nema podatka \\
\hline Carroll i Chiew (2006) & 24 studentice & 27,8 & 3,6 & nema podataka \\
\hline Dehning i sur. (2012) & 30 studentica & 21,2 & 4,0 & 0,70 \\
\hline Pfaltz i sur. (2013) & 86 studentica & 24,2 & 3,7 & nema podataka \\
\hline Vellante i sur. (2013) & 108 studentica & 25,5 & 3,5 & 0,60 \\
\hline Girli (2014) & $\begin{array}{l}160 \text { studentica } i \\
\text { zaposlenice sveučilišta }\end{array}$ & 22,5 & $\begin{array}{c}\text { nema } \\
\text { podatka }\end{array}$ & 0,71 \\
\hline Baron-Cohen i sur. (2015) & 168 ispitanica & 27,4 & 3,4 & nema podatka \\
\hline $\begin{array}{l}\text { Jankowiak-Siuda i sur. } \\
\text { (2016) }\end{array}$ & $\begin{array}{l}161 \text { ispitanica iz } \\
\text { populacije }\end{array}$ & 26,1 & 3,7 & 0,67 \\
\hline $\begin{array}{l}\text { Fernandez-Abascal i sur. } \\
\text { (2013) }\end{array}$ & $\begin{array}{l}358 \text { studenata } \\
\text { psihologije* }\end{array}$ & 27,2 & 3,6 & nema podataka \\
\hline Harkness i sur. (2010) & $\begin{array}{l}93 \text { studenta } \\
\text { psihologije }\end{array}$ & $\begin{array}{c}\text { nema } \\
\text { podatka }\end{array}$ & $\begin{array}{c}\text { nema } \\
\text { podatka }\end{array}$ & 0,58 \\
\hline Ragsdale i Foley (2011) & $\begin{array}{l}220 \text { studenata } \mathrm{i} \\
\text { ispitanika iz populacije }\end{array}$ & $\begin{array}{c}\text { nema } \\
\text { podataka }\end{array}$ & $\begin{array}{c}\text { nema } \\
\text { podataka }\end{array}$ & 0,48 \\
\hline Khorashad i sur. (2015) & $\begin{array}{l}282 \text { ispitanice iz } \\
\text { populacije }\end{array}$ & 25,2 & 6,0 & 0,37 \\
\hline \multirow[t]{2}{*}{ Prevost i sur. (2014) } & $\begin{array}{l}109 \text { ispitanica engleskog } \\
\text { govornog područja }\end{array}$ & 25,6 & 5,4 & 0,77 \\
\hline & $\begin{array}{l}99 \text { ispitanica francuskog } \\
\text { govornog područja }\end{array}$ & 24,8 & 3,8 & 0,53 \\
\hline Voracek i Dressler (2006) & 423 osobe iz populacije & 23,3 & 4,2 & 0,60 \\
\hline Olderbak i sur. (2015) & 484 osobe iz populacije* & 27,2 & 3,8 & $\begin{array}{c}\text { Koeficijent } \\
\text { pouzdanosti } \\
\text { omega } \omega=0,75\end{array}$ \\
\hline
\end{tabular}

* nema podataka odvojeno za muške i ženske ispitanike, te za studente i osobe iz populacije, ali se navode podaci za cijeli uzorak jer nije utvrđena razlika u rezultatima između ovih skupina ispitanika.

Prvi kriterij za odabir čestice temelji se na frekvenciji točnih i netočnih odgovora za svaki pojedini zadatak (Stupac 3, Tablica 3). Čestica se odabire u konačnu verziju ako je barem 50\% ispitanika odabralo točan odgovor od četiri ponuđena, a svaki od preostala tri pogrešna odgovora zaokružilo manje od $25 \%$ ispitanika. U našem istraživanju ovaj kriterij nije zadovoljilo 9 čestica, i to čestice pod rednim brojevima: 1, 2, 3, 17, 23, 25, 31, 32, 33. U ostalim istraživanjima navode se slični podaci. Npr. u španjolskoj verziji 4 čestice nisu zadovoljile navedene kriterije (Fernandez-Abascal, Cabello, Fernández-Berrocal i Baron-Cohen, 2013), u talijanskoj i turskoj verziji 7 čestica (Vellante i sur., 2013; Girli, 2014) u njemačkoj verziji 
Tablica 3. Test očiju - \% ispitanica koje su dale određeni odgovor u pojedinom zadatku i korelacija čestice s ukupnim rezultatom $(N=97)$

\begin{tabular}{|c|c|c|c|c|c|c|}
\hline \multirow{3}{*}{$\begin{array}{c}1 . \\
\text { Redni } \\
\text { broj } \\
\text { čestice }\end{array}$} & \multirow{3}{*}{$\begin{array}{c}2 . \\
\text { Slika očiju je } \\
\text { sa lica muškarca }(M) \\
\text { ili žene }(Z ̌)\end{array}$} & \multicolumn{4}{|c|}{3.} & \multirow{3}{*}{4.} \\
\hline & & \multicolumn{4}{|c|}{$\%$ ispitanica za svaki odgovor u zadatku* } & \\
\hline & & A & B & $\mathrm{C}$ & $\mathrm{D}$ & \\
\hline 1. & $\mathrm{M}$ & 48,45 & 16,49 & 20,63 & 14,43 & 0,011 \\
\hline 2. & M & 30,93 & $\mathbf{5 7 , 7 3}$ & 10,31 & 1,03 & 0,092 \\
\hline 3. & $\check{Z}$ & 0 & 2,06 & 49,48 & 48,45 & 0,000 \\
\hline 4. & M & 0 & 80,41 & 6,19 & 13,40 & 0,053 \\
\hline 5. & M & 3,09 & 14,43 & 81,44 & 1,03 & 0,219 \\
\hline 6. & $\check{Z}$ & 0 & 74,23 & 12,37 & 13,40 & $-0,068$ \\
\hline 7. & M & 6,18 & 18,56 & 52,58 & 21,65 & 0,098 \\
\hline 8. & M & 79,38 & 15,46 & 2,06 & 2,06 & 0,091 \\
\hline 9. & $\check{Z}$ & 1,03 & 4,12 & 4,12 & 90,72 & 0,074 \\
\hline 10. & M & 73,21 & 15,46 & 9,28 & 1,03 & 0,008 \\
\hline 11. & M & 12,37 & 6,19 & 73,2 & 8,25 & 0,001 \\
\hline 12. & M & 5,15 & 5,15 & 87,63 & 2,06 & 0,259 \\
\hline 13. & M & 2,06 & 77,32 & 4,12 & 16,49 & 0,185 \\
\hline 14. & M & 19,59 & 4,12 & 1,03 & 75,26 & 0,075 \\
\hline 15. & $\check{Z}$ & 94,85 & 2,06 & 1,03 & 2,06 & 0,064 \\
\hline 16. & M & 7,22 & 73,2 & 5,15 & 15,46 & 0,332 \\
\hline 17. & $\check{Z}$ & 70,10 & 28,87 & 1,03 & 0 & $-0,109$ \\
\hline 18. & $\check{Z}$ & 96,91 & 0 & 1,03 & 2,06 & 0,194 \\
\hline 19. & $\check{Z}$ & 3,09 & 6,19 & 5,15 & 83,51 & 0,187 \\
\hline 20. & M & 8,25 & 83,51 & 8,25 & 0 & 0,179 \\
\hline 21. & Ž & 11,34 & 82,47 & 6,19 & 0 & 0,409 \\
\hline 22. & $\check{Z}$ & 81,44 & 0 & 3,09 & 15,46 & 0,244 \\
\hline 23. & M & 5,15 & 10,31 & 56,71 & 27,84 & 0,203 \\
\hline 24. & M & 62,89 & 23,71 & 6,19 & 6,19 & 0,085 \\
\hline 25. & $\check{Z}$ & 1,03 & 26,80 & 10,31 & 61,86 & 0,019 \\
\hline 26. & M & 10,31 & 0 & 79,38 & 11,34 & $-0,036$ \\
\hline 27. & $\check{Z}$ & 0 & 74,23 & 16,49 & 9,28 & 0,342 \\
\hline 28. & Ž & 75,26 & 0 & 8,25 & 16,49 & 0,082 \\
\hline 29. & $\check{Z}$ & 10,31 & 5,15 & 11,34 & 73,2 & 0,056 \\
\hline 30. & Ž & 2,06 & 85,57 & 10,31 & 1,03 & 0,101 \\
\hline 31. & Ž & 7,22 & 65,98 & 0 & 26,80 & 0,021 \\
\hline 32. & M & 58,76 & 1,03 & 4,12 & 36,08 & 0,244 \\
\hline 33. & M & 6,19 & 26,80 & 3,09 & 63,92 & 0,266 \\
\hline 34. & Ž & 3,09 & 5,15 & 77,32 & 13,40 & 0,133 \\
\hline 35. & $\check{Z}$ & 12,37 & 78,35 & 6,19 & 3,09 & $-0,027$ \\
\hline 36. & M & 1,03 & 2,06 & 89,69 & 7,22 & 0,179 \\
\hline
\end{tabular}

*točan odgovor u pojedinom zadatku označen je podebljano 
testa 9 čestica (Pfaltz i sur., 2013), u francuskoj verziji 10 čestica (Prevost, Carrier, Chowne, Zelkowitz, Joseph i Gold, 2014), u iranskoj verziji 13 čestica (Khorashad i sur., 2015), itd. Budući da se uglavnom ne radi o istim česticama u različitim ispitivanjima, može se pretpostaviti da problem nastaje prilikom prevođenja riječi kojima se opisuju mentalna stanja na druge jezike. Podatak o postotku točnih odgovora u nekim radovima se navodi kao indeks težine čestica za uzorak u kojem se test primjenjuje. Neki autori smatraju da činjenica da je na neki zadatak manje od $50 \%$ ispitanika dalo točan odgovor govori o tome da je taj zadatak težak, odnosno da emocionalno stanje nije jasno prepoznatljivo na prikazanoj fotografiji. Ako je, pak, veliki postotak $(>25 \%)$ označio neki netočan odgovor kao točan, treba provjeriti jesu li ponuđene riječi dobro prevedene. U našem uzorku ovaj način analize čestica pokazuje da su dva zadatka (pod rednim brojem 1 i 3) bila vrlo teška (bilo da je nejasna fotografija ili riječ koja opisuje pripadajuće mentalno stanje) jer je manje od $50 \%$ ispitanica dalo točan odgovor, a tri zadatka (pod rednim brojem 9, 15 i 18) je točno riješilo preko $90 \%$ ispitanica, pa možemo pretpostaviti da su relativno lagani.

Drugi kriterij za odabir čestica je već ranije spomenuta prosječna korelacija među česticama. Kao što se može vidjeti u stupcu 4 (Tablica 3) neke čestice uopće ne koreliraju s ostalim česticama u testu ili je u nekim slučajevima ta korelacija čak i negativna. Od 36 čestica Testa očiju, samo njih 3 imaju zadovoljavajuću korelaciju s ukupnim rezultatom na testu $(>0,30)$, što je neprihvatljivo nisko i upozorava da se radi o sadržajima koji u maloj ili nikakvoj mjeri reflektiraju isti konstrukt. Podatak o analizi čestica i njihovoj korelaciji s ukupnim rezultatom rijetko se navodi u istraživanjima. Autor Girli (2014) utvrdio je da samo 7 čestica ima korelaciju s ukupnim rezultatom veću od 0,30 . U istraživanju Olderbaka i suradnika (2015) prosječna korelacija iznosila je 0,08 , a neke čestice su čak negativno korelirale s ukupnim rezultatom.

Treći kriterij za odabir čestica je faktorsko zasićenje. U nekim dosadašnjim provjerama faktorske strukture dobivene su petofaktorske i trofaktorske solucije (Harkness i sur., 2005; Konrath, Corneille, Bushman i Luminet, 2014; Olderbak i sur., 2015), ali ni jedna nije dala zadovoljavajuće rješenje. U prvom slučaju autori Olderbak i suradnici (2015) utvrdili su da u petofaktorskoj soluciji 27 od 36 čestica ima značajno zasićenje na pojedinim faktorima, dok 9 čestica nema zasićenje ni na jednom faktoru. Dobiveni faktori objašnjavali su mali postotak zajedničke varijance, a među njima su bile vrlo niske i neznačajne interkorelacije. U trifaktorskoj soluciji Harkness i suradnici (2005) su s obzirom na sadržaj čestica opisali faktore pozitivnog, negativnog i neutralnog afekta, no kasnije analize nisu pokazale opravdanost takve podjele.

U ovom istraživanju provjerena je faktorska struktura testa, ali dobivene nalaze treba uzeti s određenim oprezom, jer je broj ispitanika potreban za taj postupak bio nedostatan. No, budući da su u većini dosadašnjih istraživanja prezentirani rezultati dobiveni na, po veličini, sličnim uzorcima, ovdje se ipak navode ti rezultati s namjerom da posluže kao smjernica za buduća istraživanja Testom očiju. Korištena 
je eksploratorna faktorska analiza, kao i u jedinom sveobuhvatnom istraživanju faktorske strukture rezultata na Testu očiju autora Olderbaka i suradnika (2015). Ukratko, provjerom konstruktne valjanosti Testa očiju u našem uzorku, postupkom faktorske analize (metoda zajedničkih faktora uz Varimax rotaciju i Kaiser-Guttmanov kriterij ekstrakcije faktora s karakterističnim korijenom većim od 1) dobiveno je 7 faktora koji su zajedno objašnjavali $28 \%$ zajedničke varijance. Od ukupno 36 čestica Testa očiju, 5 nije imalo zasićenje veće od 0,30 ni na jednom faktoru, a veći broj čestica je imao značajno zasićenje na više faktora. Uvidom u sadržaj pojedinog faktora nije uočena logika u rasporedu čestica, te su faktori uglavnom bili neinterpretabilni. U skladu s dosadašnjim istraživanjima u sljedećem koraku provjerena je trofaktorska solucija, no i u ovom slučaju velik broj čestica imao je nisko zasićenje na pojedinom faktoru, a njihov sadržaj nije dao naslutiti da bi se moglo govoriti o pripadnosti nekom pozitivnom, negativnom ili neutralnom afektu. Od 36 čestica, čak 21 nije imala zasićenje veće ili jednako 0,30 ni na jednom faktoru, a ta tri faktora su zajedno objašnjavala $15 \%$ zajedničke varijance. Slične nalaze dobili su Vellante i suradnici (2013) i Ragsdale i Foley (2011) te su zaključili da se ova podjela ustvari ni ne može očekivati, jer se mentalna stanja opisana u testu prilično međusobno razlikuju i teško ih je grupirati u manji broj afektivnih kategorija.

Budući da autori testa smatraju da su sve čestice mjera jednog konstrukta (ma koliko on heterogen bio) i da sve imaju zasićenje na jednoj latentnoj varijabli, na kraju je provedena faktorska analiza s ograničenjem na jedan faktor. $U$ ovoj soluciji samo 8 čestica imalo je zasićenje veće od 0,30 , sa $6,4 \%$ zajedničke varijance. $\mathrm{Na}$ kraju su samo 3 čestice ispunjavale sva 3 kriterija (čestice pod rednim brojem 16, 21 i 27), što u konačnici ovaj test čini u potpunosti neupotrebljivim. Stoga je napravljen odabir čestica koje su ispunjavale prva dva kriterija (zadovoljavajući \% ispitanika koji su dali točan odgovor na određeni zadatak i faktorsko zasićenje veće od 0,30 ). Premda za ovaj postupak nema adekvatnog psihometrijskog opravdanja, u dosadašnjim istraživanjima na ovaj način se dolazilo do najkraće varijante testa koja bi bila prihvatljiva, te do podataka u kom smjeru treba planirati sljedeće korake u prilagodbi tog testa. Navedene kriterije ispunjavalo je 8 čestica (pod rednim brojem 5, 16, $21,22,24,27,33,34)$. Uvidom u karakteristike svakog od ovih 8 zadataka, opet se nije uočio neki zajednički obrazac, npr. u 4 zadatka na fotografiji bile su oči koje pripadaju ženskom, a na 4 muškom licu; u 2 zadatka je opisano neutralno emocionalno stanje, u 1 pozitivno, a u 4 negativno emocionalno stanje. No, ovako skraćeni test imao je pouzdanost tipa Cronbach alfa 0,63 (što ga svrstava u kategoriju pouzdanih mjernih instrumenata za potrebe istraživanja), a dobiveni faktor objašnjavao je $18,3 \%$ zajedničke varijance, te se mogao koristiti u daljnjim analizama. Usporedbe radi, u drugim istraživanjima broj čestica koje su imale zadovoljavajuće faktorsko zasićenje u jednofaktorskoj soluciji i koje su na kraju predstavljale skraćenu verziju testa, iznosio je redom: 10 čestica u istraživanju Olderbaka i suradnika (2015), $13 \mathrm{u}$ istraživanju autora Vellante i suradnika (2013), 17 čestica u istraživanju Konratha i suradnika (2014), i 24 u istraživanju Pfaltza i suradnika (2013). Sličnim postupkom 
Harkness, Jacobson, Duong i Sabbagh (2010) uspjeli su podići pouzdanost sa $\alpha=$ 0,58 na $\alpha=0,63$.

U svrhu provjere konvergentne valjanosti ovako skraćenog Testa očiju ispitana je njegova povezanost s rezultatima na testu kognitivne teorije uma, upitniku empatije i upitniku aleksitimije. Rezultati provedenih analiza pokazuju da su sve korelacije između Testa očiju (8 čestica) i rezultata na navedenim mjerama niske, neznačajne i negativne. U dosadašnjim istraživanjima povezanosti rezultata na $T e-$ stu očiju i ostalih mjera teorije uma dobiveni su vrlo nekonzistentni rezultati. Tako autori Zadatka kratke priče (Dodell-Feder i sur., 2013.) izvještavaju o značajnoj, pozitivnoj povezanosti rezultata na subtestu Zaključivanje o mentalnim stanjima drugih (8 čestica) i rezultata na Testu očiju $(\mathrm{r}=0,49)$. U istraživanju Torralva i suradnika (2009) povezanost između Testa očiju i testa Pogrešnog koraka bila je značajna i pozitivna $(\mathrm{r}=0,43)$. $\mathrm{S}$ druge strane, u nekim istraživanjima dobivena je neznačajna, niska korelacija između Testa očiju i ostalih mjera teorije uma: testa Neobične priče i testa Pogrešnog koraka (Ragsdale i Foley, 2011), te Protokola spontane teorije uma (STOMP) i Testa priča (Rice i Redcay, 2014). Općenito, potrebne su dodatne analize koje će razjasniti prirodu povezanosti rezultata na Testu očiju i teorije uma. Moguće je da ovaj test mjeri one aspekte teorije uma koji su u većoj mjeri kognitivni, a manje afektivni, te da odražava korištenje izvršnih funkcija u analizi facijalne ekspresije općenito, a ne specifično kao komponente teorije uma.

Ragsdale i Foley (2011) su utvrdili da je rezultat na Testu očiju značajno povezan s mjerama izvršnih funkcija (bihevioralnom inhibicijom i pažnjom). Treba spomenuti da se komorbidnost rezultata na ovom testu i mjerama izvršnih funkcija objašnjava zajedničkom neurološkom osnovom, a što je osobito bilo uočljivo kod djece s ozljedama mozga ili u neuropsihološkim studijama djece i odraslih u kojima su ispitivana teorija uma i izvršne funkcije (Ahmed i Miller, 2013; Austin, Groppe i Elsner, 2014; Carlson, Moses i Brenton, 2002; Šimleša, 2011). Ragsdale i Foley (2011) postavljaju pitanje može li se uopće teorija uma definirati kao izdvojeni konstrukt ili se radi o jednoj manje specifičnoj izvršnoj funkciji. Pri tome ne treba zanemariti činjenicu da je Test očiju više mjera izvršnih funkcija nego teorije uma, ili bar onih aspekata teorije uma koji su više povezani s izvršnim funkcijama nego sa socijalnim kognicijama. Rezultati koji idu u prilog ovakvim razmišljanjima su oni o značajnoj povezanosti Testa očiju i testova facijalne ekspresije: Bentonova testa prepoznavanja lica $(\mathrm{r}=0,43)$ i Testa lica $(\mathrm{r}=0,54)$ (Girli, 2014), te Testa sposobnosti prepoznavanja temeljnih emocija FEEL $(\mathrm{r}=0,43)$ koji uključuje fotografije lica (Pfaltz i sur., 2013)

Glede povezanosti rezultata Testa očiju i empatije dosadašnji rezultati su vrlo nekonzistentni: od izostanka značajne povezanosti s empatijom (Baron-Cohen i sur., 2015; Ragsdale i Foley, 2011; Vellante i sur., 2013; Voracek i Dressler, 2006), do značajne, pozitivne povezanosti u studentskoj populaciji $(\mathrm{r}=0,36 \mathrm{u}$ istraživanju Carroll i Yung Chiew, 2006) i u uzorcima osoba s poremećajem iz spektra autizma (Baron-Cohen i sur., 2015). Slični rezultati dobiveni su i za aleksitimiju: u nekim 
slučajevima dobivena je značajna negativna korelacija $(r=-0,43$ i $r=-0,32)$ između rezultata na Testu očiju i upitnika aleksitimije TAS-20 (Lane, Hsu, Locke, Ritenbaugh i Stonnington, 2015; Lombardo, Barnes, Wheelwright i Baron-Cohen, 2007), ili je ta povezanost izostala (Vellante i sur., 2013). Treba spomenuti da neki autori upozoravaju da se i druge, očekivane povezanosti Testa očiju pokazuju problematičnima. Npr. test je originalno konstruiran za ispitivanje teorije uma u osoba s poremećajem iz spektra autizma i u originalnom istraživanju (Baron-Cohen i sur., 2001) je njegova korelacija s kvocijentom autističnih simptoma bila očekivano visoka i značajna $(r=0,53)$. No, u nekim kasnijim istraživanjima dobivene su niske i neznačajne korelacije (Ragsdale i Foley, 2011).

Nakon provedenih statističkih analiza rezultata u našem uzorku, te pregleda rezultata u drugim istraživanjima, nameće se pitanje što se Testom očiju ustvari ispituje i koji je to latentni konstrukt koji leži u osnovi ovog testa. Neupitno je da se Testom očiju ispituju i neki aspekti kompleksne funkcije teorije uma i da je to jedan od razloga za dobivanje nekonzistentnih nalaza o njegovim psihometrijskim karakteristikama. Prepoznavanje facijalnih emocija i atribuiranje mentalnih stanja aspekti su temeljnih i složenih socijalnih kompetencija koji u sebi uključuju cijeli niz složenih procesa: (1) perceptivne sposobnosti u procesu analiziranja vizualnih informacija, njihove diskriminacije i integracije; (2) pamćenje i dosjećanje u procesu dekodiranja i povezivanja vizualnog podražaja s ranije stečenim znanjima o emocijama, te (3) kognitivne sposobnosti vezane za semantičku i leksičku analizu kojima se opaženi podražaji imenuju tako da ih druge osobe razumiju. U tom smislu, može se očekivati da se u svakom dijelu ovog procesa mogu pojaviti teškoće i da te teškoće mogu ugroziti valjanost mjernog instrumenta. No, s druge strane, to ujedno znači da se primjenom Testa očiju mogu ispitivati različite sposobnosti. Npr. za potrebe procjene socijalne kompetentnosti depresivnih osoba upravo je primjenom ovog testa upozoreno na činjenicu da su problemi u socijalnim odnosima koji su prisutni u depresivnih osoba povezani s teškoćama u dekodiranju, tj. na razini vizuospacijalnog obrasca uparivanja izraza lica s riječima koji te izraze opisuju, ali da te teškoće nestaju kada se dekodiranje vrši u nekom socijalnom kontekstu (Harkness i sur., 2005).

Prilikom prevođenja testa nametnula su se brojna pitanja vezana za semantičku i leksičku razinu. Npr. u nekim slučajevima je za neke opise emocionalnih stanja u engleskom jeziku bilo više riječi (fantasizing, contemplative, pensive, thoughtful), a u hrvatskom prijevodu jedna do dvije. Mnogi autori opisuju probleme koji nastaju u prevođenju ovog testa (vidi u Sanvicente-Vieira i sur., 2014., o postupku prevođenju s engleskog na brazilski portugalski). Neki su autori mišljenja da je nova verzija testa (iz 2001. godine), u kojoj su umjesto temeljnih emocija uvedeni suptilniji opisi, manje razumljiva i jasna, te da u toj verziji veći utjecaj ima poznavanje jezika i bogatstvo vokabulara (Ragsdale i Foley, 2011). Dodatne informacije o mogućim izvorima ovih teškoća dolaze iz rezultata istraživanja povezanosti verbalnih sposobnosti i postignuća u Testu očiju. Tako i autori testa, Baron-Cohen i sur. (2015), 
navode da je postignuće na Testu očiju povezano s verbalnim kvocijentom inteligencije i da se to može odražavati na postignuće u testu. Naime, prepoznavanje mentalnih stanja zahtijeva selekciju jedne od četiri riječi koje opisuju mentalno stanje, a rječnik mentalnih stanja koji neka osoba posjeduje može biti povezan s verbalnim IQ-om. Premda se u nekim istraživanjima opisuje značajna povezanost postignuća na Testu očiju sa verbalnim sposobnostima (Ahmed i Miller, 2013; Olderbak i sur., 2015; Peterson i Miller, 2012), drugi autori navode da nema značajne povezanosti s verbalnim IQ-om (Pfaltz i sur., 2013; Carroll i Yung Chiew, 2006).

\section{ZAKLJUČAK}

$\mathrm{S}$ obzirom na rezultate dosadašnje primjene $\mathrm{u}$ svijetu i rezultate dobivene u našem istraživanju, može se zaključiti da Test očiju ima brojnih ograničenja o kojima treba voditi računa prilikom prevođenja na druge jezike i kada se prvi put primjenjuje $\mathrm{u}$ drugim zemljama. S druge strane, test ima potencijale da bude vrlo koristan instrument za procjenu razlika u prepoznavanju kompleksnih mentalnih stanja i brojne prednosti zbog kojih smo mišljenja da bi trebalo nastaviti postupke njegove adaptacije na hrvatskom jeziku.

Kao prvo, Test očiju je vrlo jednostavan test, kako za primjenu, tako i za bodovanje. Primjena može biti u obliku papir-olovka (kao što je bilo u našem istraživanju), na kompjutorskom zaslonu ili pak on-line. Ne treba zanemariti ni mogućnosti prilagodbe testa na način da se koristi manji broj fotografija s odgovorima koji opisuju samo temeljne emocije (ljutnja, gađenje, strah, sreća, tuga i iznenađenje), kao što je to bilo u prvoj verziji testa (Baron-Cohen i sur., 2001). Test je dostupan na internetskoj stranici http://www.autismresearchcentre.com, a budući da je do danas korišten u svim navedenim oblicima, prikupljene su informacije o ponašanju testa u različitim oblicima primjene. Npr. neki autori su test koristili u svrhu mjerenja brzine reakcije u prepoznavanju facijalne ekspresije, za procjenu sposobnosti razlikovanja muških od ženskih lica, za brzinu reagiranja na pozitivne i negativne emocije i dr. (Harkness i sur., 2005; Harkness i sur., 2010; Olderbak i sur., 2015). Cijeli niz istraživanja proveden je u okviru neuropsihološke procjene, pri čemu su podaci dobiveni ovim testom korišteni zajedno s nalazima dobivenim snimanjem magnetskom rezonancom (Bodden i sur., 2013; Krach i sur., 2009; Rice i Redcay, 2014). S obzirom na to da je test preveden na brojne svjetske jezike, omogućuje komparaciju rezultata dobivenih u različitim kulturama.

Nadalje, u svim dosadašnjim istraživanjima test je pokazao dobru test-retest stabilnost i diskriminativnu valjanost (Baron-Cohen i sur., 2015; Fernandez-Abascal i sur., 2013). Usporedbom rezultata testa u kontrolnim i kliničkim uzorcima dobiveni su značajno atipični rezultati na Testu očiju u uzorcima osoba s dijagnozom anoreksije, depresije, bipolarnog poremećaja, psihopatije, poremećaja socijalne anksioznosti, shizofrenije, graničnog poremećaja ličnosti, te žrtve zlostavljanja 
i zanemarivanja i dr (Addy, Shannon i Brookfield, 2007; Baron-Cohen i sur., 2015; Girli, 2014; Harkness i sur. 2010; Laghi, Cotugno, Cecere, Siroli, Palazzni i Bosco, 2013). U tom smislu ovaj test pomaže razumjeti kako temeljne socijalno-kognitivne vještine mogu biti povezane s različitim oblicima psihopatologije.

S obzirom na to da se Test očiju pokazao uspješan u razlikovanju kliničkih od nekliničkih uzoraka, a ograničenih kvaliteta u prepoznavanju suptilnih razlika u uzorcima tipičnih odraslih ispitanika, potrebno je poraditi na njegovoj ekološkoj valjanosti, tj. upotrebljivosti testa u svakodnevnom životu kako u predviđanju socijalnih interakcija i vještine prepoznavanja emocionalnih stanja u kliničkim, tako i nekliničkim uzorcima. U ovom kontekstu najčešće se spominju poboljšanja testa pažljivim prevođenjem liste za odgovore, te uvođenjem mogućnosti korištenja rječnika s opisima mentalnih stanja. Druga mogućnost poboljšanja ekološke valjanosti vezana je za podražajni materijal koji se koristi u Testu očiju, a koji je parcijalan (dio lica) i statičan, što u stvarnom životu nikada nije slučaj. U nekim istraživanjima se pokazalo da ujednačavanje kvalitete fotografija i promjena svjetline na nekim fotografijama, može pridonijeti točnijem prepoznavanju mentalnih stanja. Istraživanja su pokazala da postoji svojevrsni "govor očiju" koji je kod osoba s poremećajem iz spektra autizma značajno oštećen (Baron-Cohen i sur., 2015), te da se one više koriste informacijama koje dobivaju iz ostalih dijelova lica, te konteksta. Navedeno ne znači da je potrebno mijenjati ispitni materijal, već da je nužno voditi računa o njegovim ograničenjima. Za sve one situacije kada se procjenjuje da bi primjena ovog testa bila problematična, autor Testa očiju sa suradnicima je razvio još dvije varijante - prepoznavanja emocija iz glasa i iz filmskog zapisa (Reading the Mind in the Voice i Reading the Mind in Films), gdje ispitanici dobivaju vizualne (facijalna ekspresija, govor tijela, aktivnosti), auditivne (verbalni sadržaj) i kontekstualne informacije (Golan, Baron-Cohen, Hill i Golan, 2006). Na kraju, budući da je ovo prva primjena Testa očiju u Hrvatskoj, rezultati upozoravaju na oprez u korištenju ovog testa bez dodatnih analiza i poboljšanja, i to kako u nekliničkim tako i u kliničkim uzorcima. U prilog ovakvom zaključku idu i rezultati iz dosadašnjih istraživanja u drugim zemljama.

\section{LITERATURA}

Addy, K., Shannon, K. i Brookfield, K. (2007). Theory of mind function, motor empathy, emotional empathy and schizophrenia. A single case study. The Journal of Forensic Psychiatry and Psychology, 18 (3), 293-306. DOI: 10.1080/09670870701292746

Ahmed, F. S. i Miller, S. (2013). Relationship between theory of mind and functional independence is mediated by executive function. Psychology and Aging, 28(2), 293-303. DOI: $10.1037 / \mathrm{a} 0031365$

Austin, G., Groppe, K. i Elsner, B. (2014). The reciprocal relationship between executive function and theory of mind in middle childhood: a 1-year longitudinal perspective. Frontiers in Psychology, 5, 1-11. 
Bagby, R. M., Parker, J. D. A. i Taylor, G. J. (1994). The twenty-item Toronto alexithymia scale -1 . item selection and cross-validation of the factor structure. Journal of Psychosomatic Research, 38(1), 23-32.

Baron-Cohen, S., Bowen, D. C., Holt, R. J., Allison, C., Auyeung, B., Lombardo, M. V., Smith, P. i Lai M. C. (2015). The "Reading the Mind in the Eyes" Test: Complete Absence of Typical Sex Difference in 400 Men and Women with Autism. PLoS ONE 10(8). DOI: 10.1371/journal.pone.0136521

Baron-Cohen, S., Wheelwright, S., Hill, J., Raste, Y. i Plumb, I. (2001). The "Reading the mind in the eyes" test revised version: A study with normal adults, and adults with Asperger syndrome or high-functioning autism. Journal of Child Psychology and Psychiatry, 42(2), 241-251.

Bernstein, D. M., Thornton, L. W. i Sommerville, J. A. (2011). Theory of mind through the ages: Older and middle-aged adults exhibit more errors than do younger adults on a continuous false belief task. Experimental Aging Research, 37, 481-502. DOI: 10.1080/0361073X.2011.619466

Bodden, M. E., Kübler, D., Knake, S., Menzler, K., Heverhagen, J. T., Sommer, J., Kalbe, E., Krach, S. i Dodel, E. (2013). Comparing the neural correlates of affective and cognitive theory of mind using fMRI: Involvement of the basal ganglia in affective theory of mind. Advances in Cognitive Psychology, 9(1), 32-43. DOI: 10.2478/v10053-008-0129-6

Carlson, S. M., Moses Lj. i Brenton C. (2002). How specific is the relationship between executive functioning and theory of mind? Contribution of inhibitory control and working memory. Infant and Child Development, 11, 73-92.

Carroll, J. M. i Yung Chiew, K. (2006). Sex and discipline differences in empathising, systemising and autistic symptomatology: evidence from a student population. Journal of Autism and Developmental Disorders. 7, 949-957.

Dahlgren Sandberg, A. i Dahlgren, S. O. (2012). Theory of mind in children with cerebral palsy: The impact of limited expressive linguistic abilities. M. Siegal i L. Surian (ur.), Access to Language and Cognitive Development (62-79), Oxford: Oxford University Press.

Dehning, S., Girma, E., Gasperi, S., Meyer, S., Tesfaye, M. i Siebeck, M. (2012). Comparative cross-sectional study of empathy among first year and final year medical students in Jimma University, Ethiopia: Steady state of the heart and opening of the eyes. $B M C$ Medical Education, 12:34. DOI: 10.1186/1472-6920-12-34

Dennis, M., Simic, N., Bigler, E. D., Abildskov, T., Agostino, A., Taylor, H. G., Rubin, K., Vannatta, K., Gerhardt, C. A., Stancin, T. i Yeates, K. O. (2013). Cognitive, affective, and conative theory of mind (ToM) in children with traumatic brain injury. Developmental Cognitive Neuroscience, 5, 25-39. DOI: 10.1016/j.dcn.2012.11.006

Dodell-Feder, D., Lincoln, S. H., Coulson, J. P. i Hooker, C. I. (2013). Using fiction to assess mental state understanding: A new task for assessing theory of mind in adults. Public Library of Science One, 8(11), 1-14. DOI: 10.1371/journal.pone.0081279

Eysenck, H. J. i Eysenck, S. B. G. (1994). Priručnik za Eysenckove Skale ličnosti (EPS odrasli). Jastrebarsko: Naklada Slap.

Ferguson, F. J. i Austin, E. J. (2010). Associations of trait and ability emotional intelligence with performance on theory of mind tasks in adult sample. Personality and Individual Differences, 49, 414-418. DOI: 10.1016/j.paid.2010.04.009 
Fernández-Abascal, E. G., Cabello, R., Fernández-Berrocal, P. I Baron-Cohen, S. (2013). Test-retest reliability of the 'Reading the Mind in the Eyes' test: a one-year followup study. Molecular Autism, 4, 1-6. DOI: 10.1186/2040-2392-4-33

Girli A. (2014). Psychometric properties of the Turkish child and adult form of "Reading the Mind in the Eyes Test". Psychology, 5, 1321-1337. DOI: 10.4236/psych.2014.511143

Golan, O., Baron-Cohen, S., Hill J. J. i Golan, Y. (2006). The 'Reading the Mind in Films' Task: Complex emotion recognition in adults with and without autism spectrum conditions. Social Neuroscience, 1, 111-123. DOI:10.1080/17470910600980986

Gršković, V. (2010). Ispitivanje odnosa emocionalne inteligencije i emocionalne kreativnosti. Odjel za psihologiju Sveučilišta u Zadru: neobjavljeni diplomski rad.

Hallerbäck, M. U., Lugnegard, T., Hjarthag, F. i Gillberg, C. (2009). The Reading the Mind in the Eyes Test: test-retest reliability of a Swedish version. Cognitive Neuropsychiatry, 14, 127-143. DOI: 10.1080/13546800902901518

Happé, F. G. E. (1994). An advanced test of theory of mind: Understanding of story characters' thoughts and feelings by able autistic, mentally handicapped, and normal children and adults. Journal of Autism and Developmental Disorders, 24(2), 129-154.

Harkness, K. L., Jacobson ,J. A., Duong, D. i Sabbagh, M. A. (2010). Mental state decoding in past major depression: effect of sad versus happy mood induction. Cognition and Emotion. 24,497-513. DOI: 10.1080/02699930902750249

Harkness, K., Sabbagh, M., Jacobson, J., Chowdrey, N. i Chen, T. (2005). Enhanced accuracy of mental state decoding in dysphoric college students. Cognition and Emotion, 19, 999-1025. DOI: 10.1080/02699930541000110

Jankowiak-Siuda, K., Baron-Cohen,S., Bialaszek, W., Dopierala, A., Kozlowska, A. i Rymarczyk, K. (2016) Psychometric evaluation of the "Reading the Mind in the Eyes" Test with samples of different ages from a Polish population. Studia Psychologica, 58, 18-31.

Khorashad, B. S., Baron-Cohen, S., Roshan, G. M., Kazemian, M., Khazai, L., Aghili, Z., Talaei A. i Afkhamizadeh M. (2015). The "Reading the Mind in the Eyes" test: investigation of psychometric properties and test-retest reliability of the Persian version. Journal of Autism Developmental Disorders, 45, 2651-2666. DOI: 10.1007/s10803015-2427-4

Kocijan Lovko, S., Gelo, J. I Karlović, D. (2015) Validation study of the Toronto Alexithimia Scale (TAS-26) in Croatian population. Acta Clinica Croatica, 54, 272-278.

Konrath, S., Corneille, O., Bushman, B. J. i Luminet, O. (2014). The relationship between narcissistic exploitativeness, dispositional empathy, and emotion recognition abilities. Journal of Nonverbal Behaviour, 38, 129-143. DOI: 10.1007/s10919-013-0164y

Krach, S., Blümel, I., Marjoram, D., Lataster, T., Krabbendam, L., Weber, J., van Os, J. i Kircher, T. (2009). Are women better mindreaders? Sex differences in neural correlates of mentalising detected with functional MRI. BMC Neuroscience, 10(9). DOI: 10.1186/1471-2202-10-9

Kulenović, A., Buško, V. i Jenjić, D. (2004). Može li Torontska skala aleksitimije (TAS-20) izmjeriti aleksitimiju odraslih i adolescenata? Suvremena psihologija, 7, 77-94.

Laghi, F., Cotugno. A., Cecere, F., Siroli, A., Palazzni, D. i Bosco, F. M. (2013). An exploratory assessment of theory of mind and psychological impairment in patients with bulimia nervosa. British Journal of Psychology, 1-15. 
Lane, R. D., Hsu, C-H., Locke, D. E. C., Ritenbaugh, C. i Stonnington, C. M. (2015). Role of theory of mind in emotional awareness and alexithymia: Implications for conceptualization and measurement. Consciousness and Cognition, 33, 398-405.

Loas, G., Corcos, M., Stephan, P., Pellet, J., Bizouard, P., Venisse, J. L., Perez-Diaz, F., Guelfi, J. D., Flament, M. i Jeammet, P. (2001). Factorial structure of the 20-item Toronto Alexithymia Scale: Confirmatory factorial analyses in nonclinical and clinical samples. Journal of Psychosomatic Research, 50, 255-261.

Lombardo, M. V., Barnes, J. L., Wheelwright, S. J. i Baron-Cohen, S. (2007). Self-Referential Cognition and Empathy in Autism. PLoS ONE 2(9). DOI: 10.1371/journal. pone. 0000883

Miller, S. A. (2009). Children's understanding of second-order mental states. Psychological Bulletin, 135(5), 749-773. DOI: 10.1037/a0016854

Muller, J., Buhner, M. i Ellgring, H. (2003). Is there a reliable factorial structure in the 20item Toronto Alexithymia Scale? A comparison of factor models in clinical and normal adult samples. Journal of Psychosomatic Research, 55, 561-568.

Muris P., Steerneman P., Meesters C., Merckelbach H., Horselenberg R., van den Hogen T. i van Dongen L. (1999). The TOM Test: A new instrument for assessing theory of mind in normal children and children with pervasive developmental disorders. Journal of Autism and Developmental Disorders, 29, 67-80.

Nettle, D. i Liddle, B. (2008). Agreeableness is related to social-cognitive, but not social-perceptual, theory of mind. European Journal of Personality, 22, 323-335. DOI: 10.1002/per.672

Olderbak, S., Wilhelm O., Olaru, G., Geiger, M., Brenneman, M. W. i Roberts, R. D. (2015). A psychometric analysis of the Reading the Mind in the Eyes Test: toward a brief form for research and applied settings. Frontiers in Psychology, 6, 1503. DOI: 10.3389/ fpsyg.2015.01503

Peterson, E. i Miller, S. F. (2012). The Eyes Test as a Measure of Individual Differences: how much of the variance reflects verbal IQ? Frontiers in Psychology, 3, 220. DOI: 10.3389/FPSYG.2012.00220

Pfaltz, M. C., McAleese, S., Saladin, A., Meyer, A. H., Stoecklin, M., Opwis, K., Dammann, G. i Martin-Soelch, C. (2013). The Reading the Mind in the Eyes Test: Test-retest reliability and preliminary psychometric properties of the German version. International Journal of Advances in Psychology Research, 2, 1-9.

Premack, D. i Woodruff, G. (1978). Does the chimpanzee have a theory of mind? Behavioral and Brain Sciences, 1 (4), 515-526.

Prevost, M., Carrier, M. E., Chowne, G., Zelkowitz, P., Joseph, L. i Gold, I. (2014). The Reading the Mind in the Eyes tests: validation of a French version and exploration of cultural variations in a multi-ethnic city. Cognitive Neuropsychiatry, 19,189-204. DOI: 10.1080/13546805.2013.823859

Ragsdale G. i Foley R. A. (2011). A maternal influence on Reading the mind in the eyes mediated by executive function: Differential parental influences on full and half-siblings. PLoS ONE, 6 (8). DOI: 10.1371/journal.pone.0023236

Remschmidt, H. (2009). Autizam: Pojavni oblici, uzroci, pomoć. Jastrebarsko: Naklada Slap. 
Rice, K. i Redcay E. (2014). Spontaneous mentalizing captures variability in the cortical thickness of social brain regions. Social Cognitive and Affective Neuroscience, 27, 1-8. DOI: $10.1093 / \mathrm{scan} / \mathrm{nsu} 081$

Sanvicente-Vieira, B., Kluwe-Schiavon, B., Wearick-Silva, L. E. Lopes Piccoli, G., Scherer, L., Tonelli, H. A. i Grassi-Oliveira, R. (2014). Revised Reading the Mind in the Eyes Test (RMET) - Brazilian version. Revista Brasileira de Psiquiatria, 36, 60. DOI: 10.1590/1516-4446-2013-1162

Šimleša S. (2011). Izvršne funkcije i teorija uma kod osoba s poremećajem iz autističnog spektra. Psihologijske teme, 20, 91-114.

Spitzer, C., Vogel., M., Barnow, S., Freyberger, H. J., \& Grabe, H. J. (2007). Psychopathology and alexithymia in severe mental illness: the impact of trauma and posttraumatic stress symptoms. European Archives of Psychiatry and Clinical Neuroscience, 257, 191-196. DOI:10.1007/s00406-006-0669-z

Taylor, G. J., Bagby, R. M. i Parker, J. D. A. (2003). The 20-Item Toronto Alexithymia Scale IV. Reliability and factorial validity in different languages and cultures. Journal of Psychosomatic Research 55, 277-283.

Torralva T., Roca M., Gleichgerrcht E., Bekinschtein T., Manes F. (2009) A neuropsychological battery to detect specific executive and social cognitive impairments in early frontotemporal dementia. Brain. 132, 1299-1309. DOI: 10.1093/brain/awp041

Vellante, M., Baron-Cohen, S., Melis, M., Marrone, M., Petretto, D. R., Masala, C. i Preti, A. (2013). The "Reading the mind in the eyes" test: Systematic review of psychomteric properties and a validation study in Italy. Cognitive Neuropsychiatry, 8, 326-354. DOI: $10.1080 / 13546805.2012 .721728$

Voracek M. i Dressler S. G. (2006). Lack of correlation between digit ratio (2D:4D) and Baron-Cohen's "Reading the mind in the eyes" test, empathy systemising, and autism quotients in general population sample. Personality and Individual Differences, 41, 1481-1491.

\title{
WHAT DOES THE EYES TEST REALLY EXAMINE? SOME METHODOLOGICAL DIFFICULTIES IN TESTING MIND THEORY USING THE EYES TEST
}

\begin{abstract}
The Reading the Mind in Eyes Test - RMET (Baron-Cohen, Wheelwright, Hill, Raste \& Plumb, 2001) or the Eyes Test, is a widely used theory of mind test in clinical and population-based samples of adults. However, little is known about the psychometric properties of this test, so the aim of the present study was to evaluate the psychometric properties of the Eyes Test according to two levels of analyses: the first was to evaluate the findings from empirical research on the psychometric analysis of the Eyes Test with special attention to the problems of test reliability and construct
\end{abstract}


validity; and the second was to analyse our own data and compare it with data from other empirical studies.

Data were obtained by the Eyes Test, administered in a sample of 97 female university psychology students. For the construct validity analyses, Short Story Task (SST) was used for assessing cognitive theory of mind, Empathy Questionnaire from the Eysenck Personality Questionnaire (EPQ-IVE/A), and Toronto Alexithymia Scale 20 (TAS-20). All tests were administered anonymously.

We present a psychometric analysis of the Eyes Test that was performed following evaluation procedures in other studies. Results indicated that the internal consistency of the Croatian version, calculated by Cronbach alpha was poor $(\alpha=0,48)$. Additionally, any significant relations with the measures of cognitive theory of mind, empathy and alexithymia were not established.

Due to serious conceptual limitations and findings about the psychometric problems, suggestions for the future use of the Eyes test are recommended.

Key words: reading the mind in the eyes test, theory of mind, psychometric analysis, empathy, alexithymia 